\title{
IMPACT OF LIFE ACTIVITY IN CONDITIONS OF DIGITAL ENVIRONMENT ON THE STUDENTS' ORGAN OF SIGHT
}

Obrubov SA, Markelova SV $\bowtie$

Pirogov Russian National Research Medical University, Moscow, Russia

The growth of eye disease incidence in the juvenile population amidst increasing visual load, which, among other factors, results from the use of electronic devices (ED), outlines the search for effective preventive measures, geared towards preservation of health of young people. The study was aimed to assess the impact of life activity upon exposure to digital environment on the organ of sight in schoolchildren and college students. The study was carried out in $2017-2020$ at Dolgoprudny gymnasium and Pirogov Russian National Research Medical University. A total of 805 schoolchildren and college students underwent ophthalmologic examination. Accommodative response was registered with Speedy-K Ver. MF-1 autorefractor keratometer (Japan). A standardized questionnaire, tailored by the authors to meet the requirements of the study, was used to assess the regime for the use of ED by students. Inclusion criteria: schoolchild, college student, ophthalmologic examination data and submitted informed consent available, correctly completed questionnaire. Statistical processing was performed using the Statistica 13.0 software. All students were the ED owners. Only $9.9 \%$ of primary school students, $2.7 \%$ of secondary school students, $1.9 \%$ of senior secondary school students, and $0.9 \%$ of college students did not use ED every day. Significant negative correlation was revealed between the students' vision acuity and the daily total time of using the ED, as well as the duration of the ED continuous use ( $\mathrm{p} \leq 0.05)$. Accommodation weakness was detected in $88.76 \%$ of students with early stage of myopia; accommodative response close to normal was less common (11.24\%). The increase in daily total time of using the ED by 2 hours and more results in higher prevalence of functional vision problems $(p \leq 0.05)$, and the trend of increasing the number of high myopia cases. The data obtained define the need of improving the students' hygiene training starting from the preschool age.

Keywords: schoolchildren, students, electronic devices, diseases of the eye, an accommodative response.

Author contribution: Obrubov SA — academic advising, data acquisition, literature analysis; Markelova SV — data acquisition, statistical processing, literature analysis, manuscript writing.

Compliance with ethical standards: the study was approved by the Ethics Committee of Pirogov Russian National Research Medical University (protocol No. 159 dated November 21, 2016). The informed consent was obtained for all the participants. The study met the requirements of biomedical ethics and involved no risk to participants.

$\triangle$ Correspondence should be addressed: Svetlana V. Markelova

Ostrovitianov str. 1, Moscow, 117997; markelova_sv@rsmu.ru

Received: 15.04.2021 Accepted: 23.05.2021 Published online: 30.06.2021

DOI: $10.24075 /$ rbh.2021.014

\section{ВЛИЯНИЕ ЖИЗНЕДЕЯТЕЛЬНОСТИ В УСЛОВИЯХ ЦИФРОВОЙ СРЕДЫ НА СОСТОЯНИЕ ОРГАНА ЗРЕНИЯ ОБУЧАЮЩИХСЯ}

С. А. Обрубов, С. В. Маркелова $\bowtie$

Российский национальный исследовательский медицинский университет им. Н.И. Пирогова, Москва, Россия

Рост пораженности детского населения болезнями глаза на фоне увеличения зрительной нагрузки, обусловленной, в том числе использованием электронных устройств (ЭУ), определяет поиск эффективных мер профилактики, направленных на сохранение здоровья молодёжи. Цель исследования - изучение влияния жизнедеятельности в условиях цифровой среды на состояние органа зрения школьников и студентов. Исследование выполнено в период 2017-2020 гг. на базе Долгопрудненской гимназии и РНИМУ им. Н.И. Пирогова. Проведен офтальмологический осмотр 805 школьников и студентов. Регистрацию аккомодационного ответа проводили с помощью автоматического аккомодографа SрееdуKverMF-1 (Япония). Для изучения режима использования ЭУ обучающимися применен стандартизованный опросник, адаптированный авторами для целей исследования. Критерии включения: школьник, студент, наличие офтальмологического осмотра и подписанного информированного согласия, корректно заполненный опросник. Статистическая обработка проведена посредством Statistica 13.0. Все учащиеся имеют ЭУ. Используют ЭУ не каждый день только 9,9\% младших школьников, 2,7\% учащихся средней школы, 1,9\% старшеклассников, 0,9\% студентов. Выявлены значимые отрицательные показатели коэффициентов корреляции между остротой зрения обучающихся и дневным суммарным временем использования ЭУ

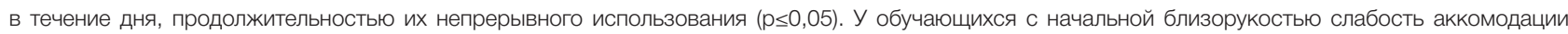
отмечалась в 88,76\% случаев, реже (11,24\%) выявлялся аккомодационный ответ, приближающийся к нормальным показателям. Увеличение дневного суммарного времени использования ЭУ первоклассниками 2 часа и более вызывает увеличение распространенности функциональных заболеваний глаза $(p \leq 0,05)$ и тенденцию к увеличению числа миопии высокой степени. Полученные данные определяют необходимость совершенствования приемов гигиенического воспитания обучающихся, начиная с дошкольного периода

Ключевые слова: школьники, студенты, электронные устройства, болезни глаза, аккомодационный ответ.

Вклад авторов: Обрубов С.А.- научное руководство, сбор материала, анализ литературы; Маркелова С.В.- сбор материала, статистическая обработка, анализ литературы, написание статьи.

Соблюдение этических стандартов: Данное исследование было одобрено ЛЭК РНИМУ им. Н.И. Пирогова (Протокол № 159 от 21.11.2016 года). Добровольное информированное согласие было получено для каждого участника. Исследование соответствовало требованиям биомедицинской этики и не подвергало опасности участников.

$凶$ Для корреспонденции: Светлана Валерьевна Маркелова ул. Островитянова, д. 1, г. Москва, 117997; markelova_sv@rsmu.ru

Поступила: 15.04.2021 Статья принята к печати: 23.05.2021 Опубликована онлайн: 30.06.2021

DOI: $10.24075 /$ rbh.2021.014 


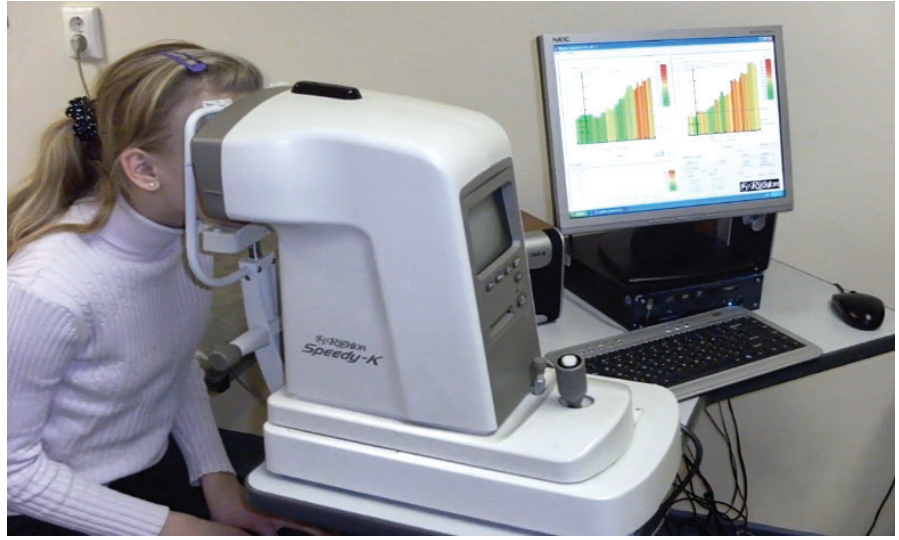

Fig. 1. Accommodative response assessment with the Speedy-K Ver. MF-1 autorefractor keratometer (Japan)

The rapidly growing usage of Internet technologies, including among children, adolescents and youth, together with younger age of users and increased duration of the Internet use by young people, were noted in the UNICEF Annual Report 2017 [1].

Digital environment substantially changes childhood and adolescence due to its contribution to many social processes (acquiring information and education, communication and maintaining social ties, entertainment and leisure activities, engagement with society and lifestyle) [2-8].

However, it is important to note the declining health of the juvenile population, especially the visual organ health. This gives relevance to development of preventive measures that would reduce adverse effects of digital environment on the health of younger generation $[9,10]$.

The study was aimed to assess the impact of life activity upon exposure to digital environment on the organ of sight in schoolchildren and college students.

\section{METHODS}

The study was carried out at Dolgoprudny gymnasium (Moscow Region) and Pirogov Russian National Research Medical University in 2017-2020. A total of 805 schoolchildren and college students underwent ophthalmologic examination (150 primary school students, 130 secondary school students, 200 senior secondary school students, 325 college students).

Visual acuity was assesed using the Golovin-Sivtsev table inserted in the Roth apparatus. The assessment results were presented in the following format: $\mathrm{Vis}^{\mathrm{no} /}{ }_{\text {correction }}(\mathrm{OD}=\ldots, \mathrm{OS}=\ldots)$. Malinovsky test was performed [11, 12].

Accommodative response was registered with the Speedy-K Ver. MF-1 autorefractor keratometer (Japan) (Fig. 1). Monocular vision was tested. Visual stimuli were presented to patient at varying distances from the eye (from infinity to 20 $\mathrm{cm}$ ), and refractive state was determined. Then the stimulus with this refraction value was presented (conditions for emmetropia were established). Later refraction of the stimulus was increased stepwise by $0.5 \mathrm{D}:-0.5 \mathrm{D},-1.0 \mathrm{D},-1.5 \mathrm{D},-2.0$ $\mathrm{D}$, etc. (up to $-5.0 \mathrm{D}$ ). Refractometer measured eye refraction amidst visual load applied many times during the study, and the data obtained went into computer to be processed and displayed in the form of diagrams. Indicators (coefficients) that characterized the ciliary muscle function were evaluated for quantification and comparative evaluation of dynamic changes in accommodography. Coefficients were calculated in the automatic mode using the specially designed software. Accommodative response coefficient reflects the degree of ciliary muscle tension. It depends on the ratio between the accommodative response and the accommodative stimulus at each "stage" of the study. Growth (decrease) in the accommodography was evaluated using the accommodography growth coefficient. Coefficient of microfluctuations is the coefficient of high frequency ciliary muscle microfluctuations [13].

The questionnaire, developed by specialists from the Research Institute of Hygiene and Health Protection of Children and Adolescents, used in multicenter studies aimed at providing medically safe digital technologies to children, was used as a basis and tailored to meet the requirements of the study reported. All authors had the following practitioner certificates: "Hygiene of Children and Adolescents", "Ophtalmology". The inclusion criteria were as follows: schoolchild, college student, informed consent submitted, ophthalmologic examination data available, questionnaire, correctly completed by the respondent or his/her legal representative. Exclusion criteria: different age group, no ophthalmologic examination data available, no correctly completed questionnaire. Correlation analysis was used to define the nature of the relationship between the students' visual acuity and their daily total time of using the $E D$, as well as the duration of the ED continuous use $(p \leq 0.05)$.

The study involved no risk to participants and met the requirements of biomedical ethics and the Declaration of Helsinki (1983). The study was approved by the Ethics Committee of Pirogov Russian National Research Medical University (protocol No. 159 dated November 21, 2016).

Statistical processing of the data was performed using the Statistica 13.0 software package.

\section{RESULTS}

No schoolchildren and college students not using electronic devices were found. Only $9.9 \%$ of primary school students, $2.7 \%$ of secondary school students, $1.9 \%$ of senior secondary school students, and $0.9 \%$ of college students did not use electronic devices every day. The students use stationary (personal computer, laptop) and mobile (smartphone, tablet) devices on a daily basis both during school day and during holidays.

Daily total time of using all electronic devices by children, adolescents and youth during school day and during holidays is presented in Table 1.

High daily total time values of using the ED both during the school day and during holidays were obtained for all categories of respondents.

During the period of study, the daily total time of using the ED (both in educational and leisure activities) was about 2.0 hours in primary school students, 5.5 hours in secondary school 
students, 8.0 hours in senior secondary school students, and 11.0 hours in college students.

During holidays, the daily total time of using the ED by primary school and secondary school students increased by an average of 0.8-1.3 hours and accounted for 2.8-3.3 hours. In senior secondary school students and college students, the daily total time of using the ED increased by an average of 1.7-3.7 hours $(p \leq 0.05)$.

When studying the students' organ of sight by computed accomodography, it was found that ciliary muscle insufficiency (weakness) was the most common accommodative state, which was in line with the data reported in literature [14].

Accommodation weakness was detected in $88.76 \%$ of students with early stages of myopia (Fig. 2). Accommodative response close to normal was less common (11.24\%) (Fig. 3).

The values of accommodative response obtained in schoolchildren with initial stages of myopia suggest poor blood circulation in long posterior ciliary arteries [15].

The relationship between the students' visual organ condition and the daily total time of using stationary and mobile electronic devices during the school day and during holidays is presented in Table 2.
Significant negative correlations were revealed between the students' visual acuity and the daily total time of using the ED, as well as the duration of the stationary and mobile electronic devices continuous use $(p \leq 0.05)$ [16].

It is shown, that with the first graders daily total time of using the ED increased by 2 hours and more, a significant decrease in a number of individuals with functional or chronic eye problems among them is observed. The prevalence ofaccommodative problems is increased $(p \leq 0.05)$, and the trend of increasing the number of high myopia cases is noted (Fig. 4).

\section{DISCUSSION}

Active development of the electronic industry over the past few decades has resulted in wide use of electronic devices, including by students in their life activities. Our findings illustrate the use of various ED types by the absolute majority of students, frequent and long-term use of ED by children, adolescents and youth during their studies, and increased visual load during holidays. The relationship between the increased duration of the stationary and mobile electronic devices continuous use, daily total time of using the ED and reduced visual acuity,

Table 1. Students' daily total time of using electronic devices during the school day and during holidays, $M \pm m, m i n$.

\begin{tabular}{|l|c|c|}
\hline \multirow{2}{*}{ Students } & \multicolumn{2}{c|}{ Daily total time of using the electronic device } \\
\cline { 2 - 3 } & \multicolumn{2}{c|}{ During the school day } \\
\hline Primary school students & $109.5 \pm 24.0$ & $154.9 \pm 27.0$ \\
\hline Secondary school students & $315.9 \pm 50.0$ & $393.3 \pm 60.0$ \\
\hline Senior secondary school students & $485.5 \pm 30.0$ & $709.8 \pm 35.0^{*}$ \\
\hline College students & $663.2 \pm 17.0$ & $767.1 \pm 19.0^{*}$ \\
\hline
\end{tabular}

Note: * $-p \leq 0.05$

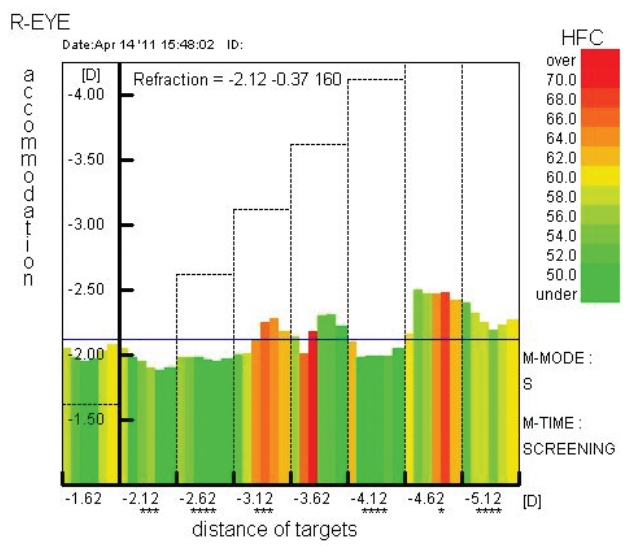

Fig. 2. Computed accomodography of the child with weak accomodation

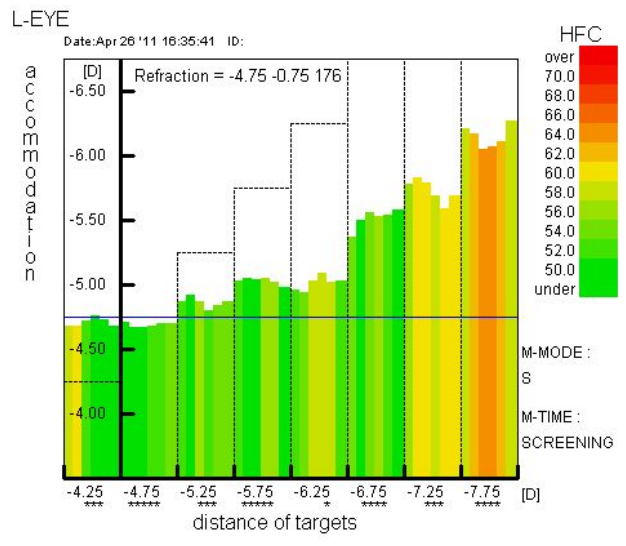

Fig. 3. Computed accomodography of the healthy child 
Table 2. Relationship between the students' visual acuity and the time of using stationary and mobile electronic devices, $\mathrm{R}^{*}$

\begin{tabular}{|l|l|l|}
\hline Time of using electronic devices & \multicolumn{2}{|c|}{ OD } \\
\hline Daily total time of using & \multicolumn{1}{|c|}{ OS } & -0.74 \\
\hline personal computer & -0.65 \\
\hline mobile electronic devices & -0.58 \\
\hline Duration of the electronic device continuous use & -0.57 \\
\hline during the school day & \\
\hline during holidays & -0.87 \\
\hline
\end{tabular}

Note:* $-p \leq 0,05$

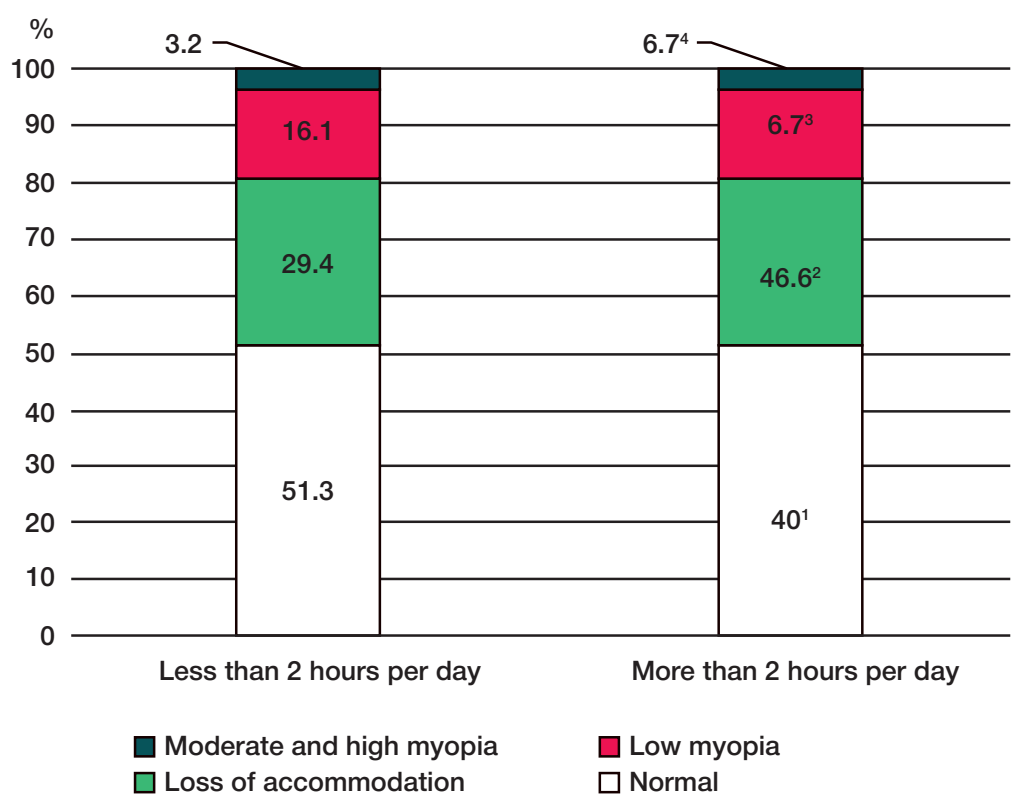

Note: $1-p \leq 0.05-$ number of first graders with normal vision;

$2-\mathrm{p} \leq 0.05-$ number of first graders with the loss of accommodation;

$3-\mathrm{p} \leq 0.05-$ number of first graders with low myopia;

$4-p \leq 0,05-$ number of first graders with moderate and high myopia.

Fig. 4. Diseases of the eye and adnexa in first graders depending on the daily total time of using the stationary and mobile electronic devices in educational and leisure activities, 2020,\%

increased prevalence of functional problems and chronic eye diseases in students had been established.

The long-term effects of using the electronic devices remain unknown. However, various short-term effects on the organ of sight, such as dry eye, burning eye, redness, blurry vision, floaters and diplopia, resulting from the use of $\mathrm{ED}$, are often reported both in domestic and foreign literature sources $[17,18]$.

This group of symptoms is known as computer vision syndrome, which can affect the users of both stationary and mobile electronic devices. According to some reports, this syndrome affects $40 \%$ of office workers, "spending at least half of their time in the office" [19].

The relationship between the organ of sight disorders and the electronic device use duration was noted by some other authors. Thus, the relationship between using the smartphone by adolescents for over 2 hours per day more than doubled the number of complaints of pain and dry eyes [20].

The symptoms listed above do not last and vanish on cessation of using the ED [21].

A whole range of measures has been developed for prevention of such organ of sight disorders. However, children, adolescents and youth show low level of awareness of the issue, and, therefore, does not acquire skills of safe ED use, which adversely affects their health, i.e. the organ of sight health, compromises their quality of life and reduces their effectiveness [22].
Such organ of sight disorders may result from impaired function of accommodation system. The condition of the accommodation system affects dynamic refraction, which in turn affects central vision. Underestimation of the role of accommodation in the development of a number of disorders may leave the students unaided and limit their visual performance at any age. Enhanced accommodation associated with the long-term use of electronic devices in children can promote postnatal growth of eyeballs and increased eye refraction. Weak accommodation precedes myopia, is considered the first sign of myopia, and accompanies the clinical course of myopia [15].

We believe that the accommodative dysfunction revealed may be due to dysregulation of the ciliary muscle function resulting from altered vegetative processes, which leads to hemodynamic changes in the ocular circulation due not only to mechanical stretching of the sclera, but also to unbalanced vascular tone neurogenic regulation [23].

Moreover, changes in choroidal perfusion can also be the probable cause of myopia progression in schoolchildren. It can be assumed that in case of increased choroidal perfusion choroid can become the source of excessive retinoid levels (retinoic acid, RA), which are unused in the biochemical reactions in the retina of individuals with myopia, and are accumulated in the known receptors of the sclera, being the closest structure [24-26]. 
RA accumulation in the sclera results in altered proliferation and differentiation of fibroblasts [27].

Further development of research in this field could contribute to eye protection in children, adolescents and youth in the context of exposure to digital environment [28-30].

\section{CONCLUSION}

Wide use of electronic devices by children, adolescents and youth against the background of increased incidence of the diseases of the eye and adnexa is of deep concern to ophthalmologists and hygienists. Studying the organ of sight disorders' pathogenesis and the revealed negative correlation between the students' visual acuity and the duration of continuous use and total daily use of the electronic devices indicate that there are some manageable risk factors, that contribute to development of this pathology. Under these circumstances, hygiene training for students aimed at acquiring knowledge and skills of safe electronic device use in the context of digital environment, as well as evolving commitment to healthy lifestyle during studies, during holidays and throughout the lifespan, should be one of the top priorities in preventive work at the current stage. Taking into account the early experience of using the ED, and the need for their use for education, preventive work should start at preschool age, and hygiene training should reach not only students, but also their parents, educators and teachers. The students' engagement with ED as a part of educational programme should comply strictly with the hygiene requirements.

\section{References}

1. Doklad JuNISEF. Polozhenie detej v mire, 2017 god: deti $v$ cifrovom mire. 11 dekabrja 2017 goda. https://www.unicef.org/ eca/ru/Otchety/doklad-«polozhenie-detej-v-mire-2017-god-detiv-cifrovom-mire» (data obrashhenija 25.03.2021). Russian.

2. Kuchma VR, Suhareva LM, Hramcov PI. Gigienicheskaja bezopasnost' zhiznedejatel'nosti detej $\vee$ cifrovoj srede. Zdorov'e naselenija i sreda obitanija. 2016; 8 (281): 4-7. Russian.

3. Kuchma VR. Gigienicheskaja bezopasnost' giperinformatizaci zhiznedejatel'nosti detej. Gigiena i sanitarija. 2017; 96 (11): 10591063. DOI: 10.18821/0016-9900-2017-96-11-1059-1063 Russian.

4. Milushkina OYu, Skoblina NA, Markelova SV, Tatarinchik AA, Melikhova EP, Libina II, Popov MV. The impact of electronic devices on the physical growth and development of the modern youth and recommendations on their safe use. Bulletin of Russian State Medical University. 2019; 4: 83-89.

5. Popov MV, Libina II. Gadzhety kak informacionnyj faktor riska i in vlijanie na sostojanie zdorov'ja molodezhi. $V$ sb. aktual'nye problemy gigieny, toksikologii i profilaktiki. Pod red. V. N. Rakitskogo. Moskva; 2019; 99-102. Russian.

6. Popov MV, Libina II, Melihova EP. Ocenka vlijanija gadzhetov na psihojemocional'noe sostojanie studentov. Molodezhnyj innovacionnyj vestnik. 2019; 8 (2): 676-678. Russian.

7. Libina II, Melihova EP, Popov MV. Issledovanie vlijanija jelektronnyh ustrojstv na sostojanie zdorov'ja studentov medicinskogo vuza. Zdorov'e molodezhi: novye vyzovy i perspektivy. Psihologicheskoe zdorov'e molodezhi. Rol' informacionnyh tehnologij. Moskva: Nauchnaja kniga; 2019; 5: 181-191. Russian.

8. Milushkina OYu, Popov VI, Skoblina NA, Markelova SV, Sokolova NV. The use of electronic devices by students, parents and teachers before and after the transition to distant learning. Bulletin of Russian State Medical University. 2020; 3: 77-82.

9. Skoblina NA, Shpakou A, Milushkina OYu, Markelova SV, Kuzniatsou A, Tatarinchik AA. Eye health risks associated with the use of electronic devices and awareness of youth. Klinika Oczna. 2020; (2): 60-65. DOI:10.5114/ko.2020.96492

10. Haertdinova Al, Shajmuhametova GF, Tolmachev DA Vlijanie jelektronnyh ustrojstv na sostojanie zdorov'ja organov zrenija studentov medicinskoj akademii. Modern Science. 2020; 12 (2): 291-294. Russian.

11. Rossijskaja oftal'mologija onlajn. Diagnostika i lechenie blizorukosti u detej. 2013. https://eyepress.ru/article.aspx?14990. (data obrashhenija 25.02.2021). Russian.

12. Baranov AA, Kuchma VR, Suhareva LM et al. Provedenie monitoringa sostojanija zdorov'ja detej i podrostkov i organizacija in ozdorovlenija. Metodicheskie rekomendacii. Moskva; 2006; 47. Russian.

13. Zharov W Komp'juternaja akkomodografija na pribore SpeedyKver MF-1 (Japonija). Metodicheskie rekomendacii. I., 2007; 24. Russian.

14. Akkomodacija: Rukovodstvo dlja vrachej. Pod red. Katarginoj LA. M.: Aprel .2012;135. Russian.

15. Boginskaja OA, Obrubov SA, Pykov Ml, Shvecova MA Ul'trazvukovaja ocenka krovotoka v sosudah glaza u detej s blizorukost'ju, sochetajushhejsja s nedifferencirovannoj displaziej soedinitel'noj tkani. Ul'trazvukovaja i funkcional'naja diagnostika. 2014; 1: 47-53. Russian.

16. Skoblina NA, Popov VI, Eryomin AL, Markelova SV, Milushkina OYu, Obrubov SA, Tsameryan AP. Risk of developing diseases of an eye and its adnexa in students in conditions of the conditions of the violation of hygienic rules for the use of electronic devices. Hygiene and sanitation. 2021; 100 (3): 279-284. Russian.

17. Kim DJ, Lim CY, Gu N et al. Visual Fatigue Induced by Viewing a Tablet Computer with a High-resolution Display. Korean J. Ophthalmol. 2017; 31 (5): 388-393. DOI:10.3341/ kjo.2016.0095

18. Long J, Cheung R, Duong $S$ et al. Viewing distance and eyestrain symptoms with prolonged viewing of smartphones. Clin Exp. Optom. 2017; 100 (2): 133-137. DOI:10.1111/cxo.12453

19. Uchino M, Schaumberg DA, Dogru $M$ et al. Prevalence of dry eye disease among Japanese visual display terminal users. Ophthalmology. 2008; 115 (11): 1982-1988. DOI: 10.1016/j. ophtha.2008.06.022

20. Moon JH, Kim KW et al. Smartphone use is a risk factor for pediatric dry eye disease according to region and age: a case control study. BMC Ophthalmol. 2016; 16: 188-194. https://doi. org/10.1186/s12886-016-0364-4

21. Kim J, Hwang Y, Kang $S$ et al. Association between Exposure to Smartphones and Ocular Health in Adolescents. Ophthalmic Epidemiol. 2016; 23 (4): 269-276. DOI:10.3109/09286586.201 5.1136652

22. Shantakumari N, Eldeeb R, Sreedharan $\mathrm{J}$ et al. Computer use and vision-related problems among university students in Ajman, United arab emirate. Ann Med Health Sci Res. 2014; 4 (2): 258263. DOI:10.4103/2141-9248.129058.

23. Porjadin GV, Boginskaja OA, Obrubov SA, Pykov MI, Kolbatova ES, Dubovik LG Osobennosti sostojanija vegetativnoj nervnoj sistemy u detej s blizorukost'ju, associirovannoj s nedifferencirovannoj displaziej soedinitel'noj tkani. In: Patologicheskaja fiziologija i jeksperimental'naja terapija. 2013; 57 (3): 27-31. Russian.

24. Ganesan P, Wildsoet CF Pharmaceutical intervention for myopia control. Expert Review of Ophthalmology. 2010; 5 (6): 759-787.

25. McFadden SA, Howlett MH, Mertz JR et al. Acute effects of dietary retinoic acid on ocular components in the growing chick. Experimental Eye Research. 2006; 83 (4): 949-961.

26. Mertz JR, Wallman J Choroidal Retinoic Acid Synthesis: A Possible Mediator between Refractive Error and Compensatory Eye Growth. Experimental Eye Research. 2000; 70 (4): 519-527.

27. Hamnagdaeva NV, Obrubov SA, Semenova LJu, Salmasi ZhM, Porjadin GV, Kazimirskij AN et al. Vlijanie all-trans retinoevoj kisloty na kul'turu skleral'nyh fibroblastov krolika. Rossijskaja detskaja oftal'mologija. 2016; 3: 18-23. Russian.

28. Milushkina OYu, Skoblina NA, Markelova SV, Tatarinchik AA, Bokareva NA, Fedotov DM Ocenka riskov zdorov'ju shkol'nikov i studentov pri vozdejstvii obuchajushhih i dosugovyh 
informacionno-kommunikacionnyh tehnologij. Analiz riska zdorov'ju. 2019; 3: 135-143. DOI: 10.21668/health.risk/2019.3.16 Russian.

29. Kuchma VR, Barsukova NK, Sankov SV Kompleksnyj podhod k gigienicheskomu normirovaniju ispol'zovanija det'mi jelektronnyh sredstv obuchenija. Zdravoohranenie Rossijskoj Federacii.
2020; 64 (3): 139-149. https://doi.org/10.46563/0044197X-2020-64-3-139-149. Russian.

30. Novikova II, Zubcovskaja NA, Romanenko SP, Kondrashhenko Al, Lobkis MA Issledovanie vlijanija mobil'nyh ustrojstv svjazi na zdorov'e detej i podrostkov. Nauka o cheloveke: gumanitarnye issledovanija. 2020; 4 (2): 95-103. Russian.

\section{Литература}

1. Доклад ЮНИСЕФ. Положение детей в мире, 2017 год: дети в цисрровом мире. 11 декабря 2017 года. https:// www.unicef.org/eca/ru/Отчеты/доклад-«положение-детей-вмире-2017-год-дети-в-цифровом-мире» (дата обращения 25.03.2021)

2. Кучма В. Р., Сухарева Л. М., Храмцов П. И. Гигиеническая безопасность жизнедеятельности детей в цисровой среде. Здоровье населения и среда обитания. 2016; 8 (281): 4-7.

3. Кучма В. Р. Гигиеническая безопасность гиперинформатизации жизнедеятельности детей. Гигиена и санитария. 2017; 96 (11): 1059-1063. DOI: 10.18821/00169900-2017-96-11-1059-1063

4. Milushkina O. Yu., Skoblina N. A., Markelova S. V., Tatarinchik AA., Melikhova EP, Libina II, Popov MV. The impact of electronic devices on the physical growth and development of the modern youth and recommendations on their safe use. Bulletin of Russian State Medical University. 2019; 4: 83-89.

5. Попов М. В., Либина И. И. Гаджеты как информационный фактор риска и их влияние на состояние здоровья молодежи. В сб: Актуальные проблемы гигиены, токсикологии и профилактики. Под ред. В. Н. Ракитского. Москва. 2019; 99-102.

6. Попов М. В., Либина И. И., Мелихова Е. П. Оценка влияния гаджетов на психоэмоциональное состояние студентов. Молодежный инновационный вестник. 2019; 8 (2): 676-678.

7. Либина И. И., Мелихова Е. П., Попов М. В. Исследование влияния электронных устройств на состояние здоровья студентов медицинского вуза. В книге: Здоровье молодежи: новые вызовы и перспективы. Психологическое здоровье молодежи. Роль информационных технологий. Москва: Научная книга. 2019; 5:181-191.

8. Milushkina O. Yu., Popov V. I., Skoblina N. A., Markelova SV Sokolova NV. The use of electronic devices by students, parents and teachers before and after the transition to distant learning. Bulletin of Russian State Medical University. 2020; 3: 77-82.

9. Skoblina N. A., Shpakou A., Milushkina O. Yu., Markelova S. V. Kuzniatsou A., Tatarinchik A. A. Eye health risks associated with the use of electronic devices and awareness of youth. Klinika Oczna. 2020; (2): 60-65. doi:10.5114/ko.2020.96492

10. Хаертдинова А. И., Шаймухаметова Г. Ф., Толмачев Д. А. Влияние электронных устройств на состояние здоровья органов зрения студентов медицинской академии. Modern Science. 2020; 12 (2): 291-294.

11. Российская офтальмология онлайн. Диагностика и лечение близорукости у детей. 2013. https://eyepress.ru/article. aspx?14990. (дата обращения 25.02.2021).

12. Баранов А. А., Кучма В. Р., Сухарева Л. М. и др. Проведение мониторинга состояния здоровья детей и подростков и организация их оздоровления. Методические рекомендации. Москва. 2006; 47

13. Жаров В. В. Компьютерная аккомодография на приборе Speedy-Kver MF-1 (Япония). Методические рекомендации. И. 2007; 24.

14. Аккомодация: Руководство для врачей. Под ред. Катаргиной Л. А. М.: Апрель. 2012; 135.

15. Богинская О. А., Обрубов С. А., Пыков М. И., Швецова М. А. Ультразвуковая оценка кровотока в сосудах глаза у детей с близорукостью, сочетающейся с недифференцированной дисплазией соединительной ткани. Ультразвуковая и функциональная диагностика. 2014; 1: 47-53.

16. Скоблина Н. А., Попов В. И., Еремин А. Л., Маркелова С. В., Милушкина О. Ю., Обрубов С. А., Цамерян А. П. Риски

развития болезней глаза и его придаточного аппарата у обучающихся в условиях нарушения гигиенических правил использования электронных устройств. Гигиена и санитария. 2021; 100 (3): 279-284.

17. Kim D. J., Lim C. Y., Gu N. et al. Visual Fatigue Induced by Viewing a Tablet Computer with a High-resolution Display. Korean J. Ophthalmol. 2017; 31 (5): 388-393. doi:10.3341/ kjo.2016.0095

18. Long J., Cheung R., Duong S. et al. Viewing distance and eyestrain symptoms with prolonged viewing of smartphones. Clin Exp. Optom. 2017; 100 (2): 133-137. doi:10.1111/cxo.12453

19. Uchino M., Schaumberg D. A., Dogru M. et al. Prevalence of dry eye disease among Japanese visual display terminal users. Ophthalmology. 2008; 115 (11): 1982-1988. DOI: 10.1016/j. ophtha.2008.06.022

20. Moon J. H., Kim K. W. et al. Smartphone use is a risk factor for pediatric dry eye disease according to region and age: a case control study. BMC Ophthalmol. 2016; 16: 188-194. https://doi. org/10.1186/s12886-016-0364-4

21. Kim J., Hwang Y., Kang S. et al. Association between Exposure to Smartphones and Ocular Health in Adolescents. Ophthalmic Epidemiol. 2016; 23 (4): 269-276. doi:10.3109/09286586.2015 .1136652

22. Shantakumari N., Eldeeb R., Sreedharan J. et al. Computer use and vision-related problems among university students in Ajman, United arab emirate. Ann Med Health Sci Res. 2014; 4 (2): 258263. DOI:10.4103/2141-9248.129058.

23. Порядин Г. В., Богинская О. А., Обрубов С. А., Пыков М. И., Колбатова Е. С., Дубовик Л. Г. Особенности состояния вегетативной нервной системы у детей с близорукостью, ассоциированной с недифференцированной дисплазией соединительной ткани. В книге: Патологическая физиология и экспериментальная терапия. 2013; 57 (3): 27-31.

24. GanesanP., Wildsoet C. F. Pharmaceutical intervention for myopia control. Expert Review of Ophthalmology. 2010; 5 (6): 759-787.

25. McFadden S.A., Howlett M. H., Mertz J. R. et al. Acute effects of dietary retinoic acid on ocular components in the growing chick. Experimental Eye Research. 2006; 83 (4): 949-961.

26. Mertz J. R., Wallman J. Choroidal Retinoic Acid Synthesis: A Possible Mediator between Refractive Error and Compensatory Eye Growth. Experimental Eye Research. 2000; 70 (4): 519-527.

27. Хамнагдаева Н. В., Обрубов С. А., Семенова Л. Ю., Салмаси Ж. М., Порядин Г. В., Казимирский А. Н. и др. Влияние all-trans ретиноевой кислоты на культуру склеральных фибробластов кролика. Российская детская офтальмология. 2016; 3: 18-23.

28. Милушкина О. Ю., Скоблина Н. А., Маркелова С. В., Татаринчик А. А., Бокарева Н. А., Федотов Д. М. Оценка рисков здоровью школьников и студентов при воздействии обучающих и досуговых информационно-коммуникационных технологий. Анализ риска здоровью. 2019; 3: 135-143. DOI: 10.21668/health.risk/2019.3.16

29. Кучма В. Р., Барсукова Н. К., Саньков С. В. Комплексный подход к гигиеническому нормированию использования детьми электронных средств обучения. Здравоохранение Российской Федерации. 2020; 64 (3): 139-149. https://doi. org/10.46563/0044-197X-2020-64-3-139-149

30. Новикова И. И., Зубцовская Н. А., Романенко С. П., Кондращенко А. И., Лобкис М. А. Исследование влияния мобильных устройств связи на здоровье детей и подростков. В книге: Наука о человеке: гуманитарные исследования. 2020; 4 (2): 95-103. 